\title{
Doseljavanje stanovništva iz slovenskih krajeva u župe Središnjega kraja i Kupske doline na temelju zabilješki u knjigama Stanje duša od sredine 19 . do sredine 20 . stoljeća
}

DOI: $10.11567 /$ met.30.1.4 UDK:314.742(497.5-3Gorski kotar:497.4)"18/19" Prethodno priopćenje Primljeno: 2.1.2014. Prihvaćeno: 7.5 .2014 .

\section{Barbara Riman}

Inštitut za narodnostna vprašanja, Ljubljana

barbara.riman@guest.arnes.si

\begin{abstract}
SAŽETAK
Razlog današnjega heterogenog sastava stanovništva Gorskoga kotara potrebno je tražiti u različitim migracijskim procesima. Izuzetak $u$ tim procesima nisu bili ni Središnji kraj ni Kupska dolina, te je kroz povijest zabilježeno doseljavanje stanovništva iz različitih dijelova nekadašnje Habsburške Monarhije. Razloge doseljavanja stanovništva i intenzitet njihova dolaska može se pratiti po zapisima u knjigama Stanje duša, gdje su zabilježeni razlozi dolaska ili odlaska pojedinaca, ali i cijelih obitelji. Na temelju tih podataka mogu se izvući uopćeni zaključci za određeni geografski prostor i političko-povijesno razdoblje. U radu se razmatraju podaci o doseljavanju stanovništva u Središnji kraj i Kupsku dolinu, s naglaskom na doseljavanje stanovništva iz današnjih slovenskih krajeva od sredine 19. do sredine 20. stoljeća. Podaci dobiveni iz knjiga Stanje duša iz župa Središnjega kraja i Kupske doline upućuju na doseljavanje stanovništva, što dokumentira postojanje migracija iz slovenskih krajeva prema današnjim hrvatskim područjima, ali i obratno. Izneseni zaključci nadopunjeni su i ilustrirani podacima iz matica učenika osnovnih škola u Brodu Moravicama, Brodu na Kupi, Crnom Lugu, Delnicama, Divjakama, Fužinama, Lokvama, Skradu, Razlogama i Vrbovskom.
\end{abstract}

KLJUČNE RIJEČI: Stanje duša, Središnji kraj, Kupska dolina, Gorski kotar, doseljavanje slovenskog stanovništva

\section{UVOD}

Gorski kotar, brdsko područje koje povezuje obalu s unutrašnjošću, sastavni je dio Primorsko-goranske županije i geografski se može podijeliti 
na pet mikroregija, od kojih su dvije Središnji kraj i Kupska dolina ${ }^{1}$ (Šafar, 1981).

Središnji se kraj rasprostire od Severinskoga kraja na krajnjem istoku do Gornjeg Jelenja na krajnjem zapadu, a na jugoistoku završava kod Mrkoplja i Ravne Gore. Za taj su prostor značajni krški reljefni oblici, a u njegovu središnjem dijelu nalaze se Delnice, najveće goransko regionalno središte. Središnji je kraj zbog relativno reljefno ravnih prostora otvoreniji i prohodniji od ostatka Gorskoga kotara.

Kupska je dolina izrazito gorski prostor koji obuhvaća prostor od izvora Kupe do Severina, a prometno je, za razliku od Središnjega kraja, slabo povezana s Rijekom i Zagrebom. Upravo su zato hrvatska, ali i slovenska naselja u pograničnom prostoru okrenuta jedna drugima (Šafar, 1981: 21). Na to je utjecala i činjenica da nema većih kulturnih ni etnografskih razlika tih pograničnih prostora (Bognar i Bognar, 2010: 216). Zbog prirodnih prepreka Kupske i Čabranske doline te udaljenosti od većih središta taj je kraj postao zatvoren (Knežević-Hočevar, 1999: 103) te se upravo zato razvila posebna povezanost stanovništva na mikrorazini (Melik, 1959: 472).

Geografske karakteristike Gorskoga kotara utjecale su na povijesne događaje. Gorski kotar prostor je nepovoljne klime i reljefa, zbog čega nije bio privlačan za doseljavanje i dugotrajan život te je to jedan od razloga što su ga zaobišla masovnija migracijska kretanja. Doseljavanje u kolonizacijskim valovima uglavnom je ovisilo o nastojanju feudalnih gospodara da ponovo nasele stanovništvo u krajeve opustošene osmanskim upadima. ${ }^{2}$ To je bilo organizirano doseljavanje, ali zabilježeno je i samoinicijativno doseljavanje, prije svega jer su ljudi procijenili da ih u Gorskom kotaru čekaju bolji životni uvjeti. Pojedinačni dolasci često su bili potaknuti i intimnim razlozima poput sklapanja braka.

Najintenzivnije doseljavanje zabilježeno je tijekom 18. stoljeća zbog gospodarskog procvata Gorskoga kotara, čemu je pridonijela izgradnja Karoline, $^{3}$ a poslije i Lujzijane ${ }^{4}$ (Borovac, 2002: 272). Za doseljavanje je bio

1 Ostale su tri mikroregije Čabarski kraj, Severinski kraj i Drežnički ili Velikokapelski kraj (Šafar, 1981).

2 Više o osmanskim upadima: Malnar, 2007: 27-29; Šafar, 1981: 51; Burić, 1983: 14-16; Radanović, 1981: 13.

3 Prva cesta, Karolina, počela se graditi 1726. Ime je dobila prema caru Karlu VI. Pripreme su trajale nekoliko godina. Izgrađena cesta bila je duga 105 kilometara i imala dva smjera, prema Bakru i Rijeci. Bila je to vrlo uska cesta sa strmim i oštrim zavojima (Horvat, 1980: 21-25).

4 Druga je cesta Lujzijana, čija je gradnja trajala od 1804. do 1811. Ime je dobila po supruzi habsburškog cara Franje. Cesta je nastala zbog državnih i vojnih potreba. Njezinu gradnju inicirao je biskup Maksimilijan Vrhovec (Horvat, 1980: 119-120). 
važan i razvoj željezničkog prometa, odnosno završetak izgradnje željezničke pruge Rijeka - Karlovac 1873. Važnu je ulogu u migracijama imao i razvoj drvne industrije. Upravo je ona od svojih početaka bila povezana s radnicima koji su se doseljavali iz slovenskih krajeva te sa slovenskim investitorima i vlasnicima pilana koji su potjecali s prostora današnje Slovenije. Industrijski su centri bili u Vrbovskom, Delnicama i Fužinama te nekim manjim naseljima kao što su Josipdol, Vrata, Gerovo i Skrad (Borovac, 2002: 273).

Doseljavanje stanovništva u Gorski kotar trajalo je od prestanka osmanskih upada do sredine 19. stoljeća (Bognar i dr., 1975: 97), kada je zabilježen suprotni demografski proces - depopulacija. ${ }^{5}$ Nepovoljna prirodno-geografska osnova i nedostatak obradivih površina u goranskoj regiji stvorili su višak poljoprivrednog stanovništva, pa to područje poprima obilježja emigracijskoga i depopulacijskoga kraja. Prema popisu stanovništva iz 1910., oko četrdeset posto goranskog stanovništva vodilo se kao privremeno odsutno, što govori o jačini emigracije. Najjači emigracijski tokovi bili su usmjereni prema Americi, ali i gospodarski razvijenijim dijelovima Hrvatske. Tu je posebno važno spomenuti odlaske goranskog stanovništva u Slavoniju ${ }^{6}$ (Lajić i Klempić Bogadi, 2010: 191-192). Mogućnost dnevnih migracija prema Sloveniji (Metlika, Kočevje, Cerknica i sl.) i većim regionalnim centrima Hrvatske (Karlovac, Rijeka) nije bitno utjecala na demografsku regresiju. Na taj zaključak navode i različiti podaci dobiveni iz pregledanih knjiga Stanje duša (lat. status animarum). Iseljavanje se nastavilo nakon Drugoga svjetskog rata, što se negativno odrazilo na dobni sastav stanovništva. Danas je društveno-gospodarska organizacija života pograničnog prostora Hrvatske i Slovenije uglavnom prilagođena današnjoj granici (Bognar i Bognar, 2010: 217).

O migracijama na prostoru Gorskoga kotara, a time i Središnjega kraja i Kupske doline, pisalo se, ali ne na temelju podataka dobivenih iz knjiga Sta-

Depopulacija se širila etapno. Prvo je zahvatila Gorski kotar i Pokuplje te se proširila na cijelu Gorsku Hrvatsku. Smatra se da je od polovine 19. stoljeća do kraja Drugoga svjetskog rata Gorski kotar izgubio oko 1.308 .000 stanovnika, i to $42 \%$ zbog vanjskih migracija, 17,6\% zbog epidemija i 40,3\% zbog gubitaka u Prvome i Drugome svjetskom ratu (Nejašmić, 1991: 268-269).

6 U prilog tome govori i zanimljiv podatak. Stjepan Stepanov, melograf iz Slavonije, sakupljajući pjesme po slavonskim selima, slučajno je zapisao i one koje su se pjevale u Gorskom kotaru. Očigledno se u mjesto Niza u Slavoniji doselio veći broj ljudi iz Čabarskoga kraja, koji su zadržali svoje običaje i kulturu. U Slavoniju nisu odlazili samo stanovnici Gorskoga kotara, već su tamo bolje životne uvjete tražili i stanovnici slovenskih krajeva, koji su onamo odlazili najčešće zimi na sezonske poslove. Njih su nazivali hrvatarji (Drnovšek, 1995: 107-113). Zabilježeno je i da su na sezonski posao uz muškarce odlazile i žene, najviše iz Prekmurja (Kuzmič, 1995), koje su bile slabije plaćene (Drnovšek, 2012: 136). 
nje duša. Povijesna se demografija za prostor Gorskoga kotara, kao i druge znanstvene grane, pretežno bavila procesom iseljavanja stanovništva i u te su analize vrlo rijetko bili uključeni procesi doseljavanja.

Prema podacima u knjigama Stanje duša mogu se vidjeti, između ostaloga, i procesi doseljavanja te se tako može dobiti uvid u kretanje stanovništva. Ovdje će u prvom redu biti riječ o dolascima ljudi (pojedinaca, a rjeđe i cijelih obitelji) i razlozima njihova doseljavanja. Izneseni zaključci bit će važni i na mikrorazini Središnjega kraja i Kupske doline, po čemu se može zaključivati o procesima na razini zavičajne povijesti. Analizom prikupljene građe moguće je uočiti i postojanje dosad nezabilježenih veza između slovenskog i hrvatskog stanovništva. Ujedno će se predstaviti procesi doseljavanja koji su slični, ako ne i jednaki ne samo u ovdje prikazanim prostorima već i u cijelome slovensko-hrvatskom pograničnom prostoru.

Dosad su se razlozi doseljavanja vidjeli u onih doseljenika koji su svojim radom zadužili naselje u koje su došli te je šira javnost bila upoznata s njihovim životom. To su uglavnom bili političari, intelektualci i druge javne osobe koje su svojim djelovanjem zadužile sredinu u koju su došle te se stoga analiziralo njihove živote, motive dolaska i rada te zasluge i o njima se često pisalo u knjigama dotičnoga kraja. Analizom zabilješki u knjigama Stanje duša mogu se vidjeti razlozi dolaska ljudi koji se nisu isticali i čiji bi razlozi dolaska bez tih knjiga ostali nepoznati.

Radom se ujedno želi upozoriti na važnost knjiga Stanje duša kao izvora u znanstvenoistraživačkoj djelatnosti. Sve više znanstvenika različitih struka poseže upravo za matičnim knjigama te za knjigama Stanje duša. ${ }^{7}$

Cilj je rada upozoriti na veze među slovenskim i hrvatskim pograničnim, ali i udaljenijim naseljima, koje su se razvijale stoljećima. Riječ je o naseljima dviju mikroregija i različitim slovenskim naseljima, kako onima u pograničnom prostoru tako i onima udaljenijima od slovensko-hrvatske granice.

Ovdje navedeni podaci sakupljeni su iz knjiga Stanje duša prenesenih na mikrofilmove, čije se kopije nalaze u Državnom arhivu u Rijeci (DAR). Podaci su prikupljeni segmentno jer se odnosne samo na doseljavanje stanovništva iz slovenskih krajeva, a ne i na druge doseljenike. Za župu Sv. Nikole

\footnotetext{
Matične knjige (knjige krštenih, knjige vjenčanih, knjige umrlih i knjige Stanje duša) zastupljene su $\mathrm{u}$ istraživanjima i prepoznate kao važan i vjerodostojan izvor podataka $\mathrm{u}$ različitim znanostima. Upotrebljavaju ih povjesničari, etnolozi, antropolozi i znanstvenici drugih grana (Bertoša, 2000, 2001; Senčić, 2000; Žigulić, 2008). Povijesni pregled očuvanih matičnih knjiga na prostoru Hrvatske dan je u djelu Povijesna demografija Hrvatske (Stipetić i Vekarić, 2004), a predstavljena su i istraživanja i značajni radovi hrvatske povijesne demografije do 2004. Nažalost, iz ovog pregleda radova vidljiv je slab interes hrvatskih znanstvenika za migracijske procese i kretanje stanovništva u geografskom prostoru o kojem je ovdje riječ.
} 
u Brodu Moravicama pregledana je knjiga Stališ duša župe Brod-Moravice (DAR, DVD 4, ZM-34J-206), koja obuhvaća razdoblje od 1911. do 1954.

Za župu Sv. Petra i Pavla apostola u Crnom Lugu pregledana je knjiga Stališ duša župe Crni Lug (DAR, DVD 04, ZM-34J-207), koja obuhvaća razdoblje od sredine 19. do sredine 20. stoljeća.

Za župu Sv. Ivana Krstitelja u Delnicama pregledane su dvije knjige Stanje duša delničke župe: Stališ duša Delnice, Status animarum XIX-XX. st. (DAR, DVD 4, ZM-34J-210; ZM-34J-211) i Svezak II, Status animarum XIX-XX. st. (DAR, DVD 4, ZM-34J-210; ZM-34J-211). Knjige obuhvaćaju razdoblje od sredine 19. do početka 21. stoljeća.

Za župu Sv. Izidora ratara u Divjakama-Skradu pregledana je Knjiga stališa duše župe Divjake (DAR, DVD 7, ZM-34-J-226), koja obuhvaća razdoblje od sredine 19. do sredine 20. stoljeća.

Za župu Sv. Ivana Padovanskog u Fužinama pregledane su dvije knjige: Stališ duša Fužine (DAR, 05, ZM-34-J-218) i Stališ duša župe Fužina (DAR, 05, ZM-34-J-218).

Za župu Sv. Katarine djevice i mučenice u Lokvama pregledana je knjiga Status animarum XIX-XX. st. (DAR, 05, ZM-34-J-213; 05, ZM-34-J-214), koja obuhvaća razdoblje od sredine 19. do sredine 20. stoljeća.

Za župu Sv. Petra i Pavla apostola u Podstenama pregledana je knjiga Stališ duša (DAR, DVD 05, ZM-34J-214), koja obuhvaća razdoblje od kraja 19. do sredine 20. stoljeća.

Za župu Sv. Terezije Avilske u Ravnoj Gori pregledane su knjige: Stališ duša Ravna Gora (DAR, DVD 6, ZM34J-223), Stališ duša Ravnogorci (DAR, DVD 6, ZM34J-223), Status animarum 1906-1950 (DAR, DVD 6, ZM34J-223; DVD 6, ZM34J-224) koje obuhvaćaju razdoblje od sredine 19. do sredine 20. stoljeća

Za župu Sv. Ivana Nepomuka u Vrbovskom pregledana je knjiga Stališ duša (DAR, DVD 6, ZM34J-226), koja obuhvaća razdoblje od 1861. do 1961.

Podaci iz pregledanih knjiga odnose se ravnopravno na muškarce i žene za koje je pisalo da su rođeni u nekome slovenskome mjestu, odnosno na prostoru neke slovenske župe. U nekim je slučajevima župnik zapisao samo da se osoba doselila iz Slovenije, no takvih je primjera relativno malo.

Pri obradi podataka pojavio se problem periodizacije dolaska zabilježenih osoba jer u pregledanim knjigama Stanja duša izuzetno je rijetko zabilježena godina dolaska. Najčešće piše godina vjenčanja para ako je migracija bila potaknuta obiteljskim razlozima. Ako je razlog dolaska bio neki drugi, preuzeta je godina koju je župnik zapisao kao godinu dolaska, iako je to 
rijetko. Zbog tih objektivnih razloga vremenska dimenzija dolazaka nije analizirana detaljno, već onoliko koliko su prikupljeni podaci dozvoljavali.

Svakako je važan i geografski položaj župe. Ako se nalazi u pograničnom prostoru, očekuje se veći broj doseljenika koji su se doseljavali isključivo zbog vjenčanja. Ako se župa nalazi u prostoru koji nije pograničan te je prostor župe udaljeniji od granice, očekuje se manji broj doseljenika, a i razlozi su doseljavanja drugačiji. ${ }^{8}$ Pretpostavljali smo da će više biti zabilježeni dolasci motivirani osnivanjem obitelji (vjenčanje), a manje poslom te da će uz zabilježene individualne dolaske biti registrirani i dolasci cijelih obitelji.

Na doseljavanje stanovništva u pojedina naselja ovdje analiziranih župa utjecali su i vanjski čimbenici: prometna infrastruktura (prometna povezanost pojedinih naselja), geografski čimbenici (gorski masiv), crkvenoupravni, državno-upravni i dr. (Josipovič, 2006: 204). Oni su vidljivi upravo pri konačnoj analizi migracija. ${ }^{9}$

Prikupljeni podaci prikazani su po župama, koje su poredane abecednim redom naselja u kojem je sjedište župe. Podaci dobiveni iz Stanja duša upotpunjeni su onima iz matica učenika goranskih škola u Brodu Moravicama, Brodu na Kupi, Crnom Lugu, Delnicama, Divjakama, Fužinama, Lokvama, Skradu, Razlogama i Vrbovskom. Ti su podaci samo ilustrativni i upućuju na procese povezivanja koji nisu vidljivi iz knjiga Stanje duša. Valja naglasiti da su selektivni jer su iz njih isključeni doseljenici koji nisu imali djecu školske dobi. No i ti su podaci važni da bi se predstavio što cjelovitiji mozaik slovenskog preseljavanja, ali i povezivanja u smjeru Središnjega kraja i Kupske doline.

8 Preuzeta je klasifikacija razloga doseljavanja stanovništva iz slovenskih krajeva u Hrvatsku koju je razvila V. Kržišnik-Bukić (1994/1995). Najviše se ljudi iz slovenskih mjesta doseljavalo zbog posla i zarade. Ostali su razlozi: bijeg iz Kraljevine Italije između dva svjetska rata i tijekom Drugoga svjetskog rata, sklapanje brakova Slovenki i Slovenaca sa stanovnicima hrvatskih krajeva, studij i školovanje te seljenje u hrvatske krajeve nakon umirovljenja (Kržišnik-Bukić, 1994/1995: 92). Njezinu klasifikaciju preuzimamo i zbog činjenice da su sve teorijske podjele uzroka migracije preopćenite za konkretni primjer Središnjega kraja i Kupske doline, koji, poput svih drugih krajeva, imaju lokalne i kulturno-političke specifičnosti.

9 Ovdje valja spomenuti migracije zbog zaposlenja (posla), koje pripadaju pseudodobrovoljnim migracijama. Naime iako se čini da je dolazak određenog pojedinca, a onda i njegove obitelji bio dobrovoljan, valja imati na umu da bi njegov nedolazak vjerojatno značio otpuštanje iz službe (Josipovič, 2006: 194). Ovdje se to uglavnom odnosi na državne i crkvene službenike, prije svega u razdoblju Austro-Ugarske Monarhije (Šuštar, 2010: 209). 


\section{ŽUPA SV.IVANA KRSTITELJA U BRODU MORAVICAMA}

Naselje koje danas nosi ime Brod Moravice kroz povijest je izmijenilo mnogo naziva: Moravice, Gornje Moravice, Turanj te Brodske Moravice. Naselje je postojalo već u 13. stoljeću, a razvilo se u 16., kada je bilo u posjedu knezova Frankopana. Župa Brod Moravice vrlo je stara i uz župu u Gerovu jedna je od najstarijih u Gorskom kotaru. Osnovana je između 1300. i 1400. (Jurković, 1969: 21).

Iz knjige Stališ duša župe Brod-Moravice (DAR, DVD 4, ZM-34J-206) vidi se da su se ljudi uglavnom iseljavali, i to prije svega u veća hrvatska naselja kao što su Zagreb i Rijeka, ali i da su napuštali zemlju i odlazili u države na drugim kontinentima. Doseljavanje stanovništva zabilježeno je prije svega iz okolnih goranskih naselja (Divjake, Delnice itd.), a manji je broj doseljenika iz slovenskih naselja. Od 1911. do 1954. u naselja župe Brod Moravice doselilo se deset stanovnika iz slovenskih naselja, troje iz Slovenije ${ }^{10}$, dvoje iz Vinice i po jedan iz Spodnjeg Loga, Starog Loga, Starog Trga, Trnovice i Velike Doline. U ukupnom broju doseljenika bilo je sedam žena i tri muškarca. Za tri osobe vrijeme dolaska nije zapisano, tri su došle prije 1918., dvije između dva svjetska rata, a dvije nakon Drugoga svjetskog rata. Razlog dolaska najčešće je bio osnivanje obitelji, a zabilježeni su samo podaci koji se odnose na obiteljsko stanje, pa nema podataka o zanimanju.

Brod Moravice župa je u pograničnom prostoru i očekivani razlozi doseljavanja uglavnom su vezani uz osnivanje obitelji. No broj dolazaka manji je od očekivanoga u usporedbi s drugim naseljima pograničnih župa. Razloge slabijeg doseljavanja možemo pronaći u relativno lošoj cestovnoj povezanosti sa slovenskim krajevima i udaljenosti naselja od glavnih prometnica.

\section{ŽUPA SV.PETRA I PAVLA APOSTOLA U CRNOM LUGU}

Župa Crni Lug osnovana je 1817., a danas njome upravlja župnik iz Lokvi. ${ }^{11}$ Knjiga Stališ duša župe Crni lug (DAR, DVD 04, ZM-34J-207) numerirana je te su zapisani i brojevi kuća. Iz knjige je vidljivo da je stanovništvo napuštalo prostor župe i da je bolje životne uvjete tražilo u drugim hrvatskim naseljima, ali i u drugim državama.

U razdoblju koje obuhvaća knjiga zabilježene su samo četiri osobe (dvije žene i dva muškarca) koje su se iz slovenskih naselja doselile u Crni Lug. Doselile su se iz mjesta Dolenja Vas pri Ribnici, Fara pri Kostelu, Kočevje

10 Za tri je osobe zapisano samo »Slovenija«, a ne i naselje.

11 Osim mjesta Crni Lug župa obuhvaća mjesta: Leska, Malo Selo, Šibrlečka, Vela Voda, Zelin Crnoluški, Biljevina, Bijela Vodica, Tumac, Jarak i Stranac (Kovač, 1993: 50-51). 
i Velike Vode, koja se nalaze u slovenskome pograničnom prostoru. Svi su došli iz obiteljskih razloga, između dva svjetska rata.

Tako slab intenzitet doseljavanja očekivan je jer na prostoru župe Crni Lug nije bilo industrije, a naselja župe udaljena su od većih središta i glavnih prometnica. Osim toga Crni Lug, kao i ostala naselja koja pripadaju toj župi, odijeljen je od slovenskih krajeva, kao i od Čabarskoga kraja, šumskim koridorom, ali i gorskim masivom, što dodatno otežava komunikaciju sa slovenskim krajevima.

\section{ŽUPA SV.IVANA KRSTITELJA U DELNICAMA}

Delnice su jedno od najvećih i najstarijih goranskih naselja. Kroz stoljeća su bile društveno-političko, gospodarsko, administrativno, kulturno i sportsko središte goranske regije (Šisler, 2008: 595). ${ }^{12}$ Naselje je dobilo važnost nakon izgradnje Karolinške i Lujzijanske ceste, kada počinje ponovno doseljavanje stanovništva u današnje Delnice i okolicu. Upravo je prometna povezanost utjecala na razvoj Delnica. U 18. stoljeću počelo se razvijati prijevozništvo, čime su se ostvarili i uvjeti za otvaranje gostionica i prenoćištâ. S početkom gradnje željeznice u mjesto su se počeli doseljavati obrtnici i radnici na željeznici. Dio stanovništva pronalazio je posao na željezničkoj trasi od Ogulina do Rijeke, a veći se dio sa svojim kolima i stokom uključio u različite grane šumskoga gospodarstva (Mateljan Radovanović, 1981: 23).

Iz zabilješki u knjigama Stanje duša (DAR, DVD 4, ZM-34J-210/ZM-34J$211)^{13}$ vidljivo je da su se od kraja 19. pa sve do sredine 20. stoljeća doseljavali ljudi rođeni u raznim europskim državama, npr. u Mađarskoj ili Njemačkoj. Iako su zabilježeni dolasci, oni su u odnosu na odseljavanje znatno manji. Tako je vidljivo da su ljudi odlazili u druga hrvatska naselja, prije svega u Slavoniju i gradove na obali, ali i na druge kontinente.

Pregledane knjige na kraju su imale rubriku Inostranci te su tako neki pojedinci u knjigama zabilježeni dvaput. Prvo su zabilježeni na stranici na kojoj je zapisana obitelj u koju su došli, odnosno kuća u kojoj su živjeli, a potom u rubrici Inostranci (tablica 1).

12 Toponim Delnice prvi se put spominje 1481.

13 Knjige Stanje duša (DAR, DVD 4, ZM-34J-210/ZM-34J-211) vođene su na hrvatskom jeziku, numerirane i paginirane. Tinta kojom su ispisivane na nekim je mjestima jako izblijedjela, tako da nije bilo moguće pročitati sve zabilješke. U drugoj knjizi, Svezak II, nedostaju stranice od 51. do 80. (DAR, DVD 4, ZM-34J-210/ZM-34J-21: MO 1803967). 
Tablica 1. Doseljenici na prostor župe Sv. Ivana Krstitelja u Delnicama od sredine 19. do početka 21. stoljeća prema mjestu odakle su doselili

Table 1. Immigrants in the area of St. John the Baptist Parish in Delnice in the period from the mid- $19^{\text {th }}$ to the beginning of the $21^{\text {st }}$ century, by place of emigration

\begin{tabular}{lc|lc}
\hline Slovenska naselja & $\begin{array}{c}\text { Broj } \\
\text { doseljenika }\end{array}$ & Slovenska naselja & $\begin{array}{c}\text { Broj } \\
\text { doseljenika }\end{array}$ \\
\hline Banja Loka & 2 & Polzela & 1 \\
\hline Borovec & 1 & Potok & 1 \\
\hline Celje & 1 & Preserje & 1 \\
\hline Črneča Vas & 1 & Radgona & 1 \\
\hline Fara pri Kostelu & 9 & Rakek & 1 \\
\hline Grivac & 1 & Ribnica & 1 \\
\hline Lokev & 1 & Selo & 1 \\
\hline Loški Potok & 1 & Slavski Laz & 1 \\
\hline Ložec & 1 & Slovenska Vas-Kočevje & 1 \\
\hline Nova Sela & 1 & Sodražice & 1 \\
\hline Osilnica & 2 & Stari Trg & 1 \\
\hline Pirče & 2 & Trnava & 2 \\
\hline Podgorje & 1 & Vas pri Kostelu & 39 \\
\hline Podturn (Toplice) & 1 & Ukupno & \\
\hline
\end{tabular}

Kao što se vidi iz tablice 1, u Delnice se iz slovenskih naselja doselilo 39 osoba. Od toga ih je 27 došlo iz slovenskoga pograničnog prostora, a dvanaest iz naselja udaljenijih od granice. Zabilježen je dolazak dvadeset žena i devetnaest muškaraca. Od toga su bila četiri bračna para, za koja nije napisan razlog dolaska. Možemo pretpostavljati da su došli zbog boljih životnih uvjeta ili u potrazi za poslom, ali potvrde za takve tvrdnje nemamo. Za dva je muškarca zapisano zanimanje, jedan je bio lugar (DAR, DVD 4, ZM-34J-210/ZM-34J-211: MO 1803676; Matična knjiga br. 5. (1905./1906.1909./1910., 1905/1906), a drugi kovač (DAR, DVD 4, ZM-34J-210/ZM34J-211: MO 1803975; Matična knjiga br. 7., 1919/1920). Valja spomenuti da je taj kovač sa svojom obitelji bio u Delnicama do 1922., kada se odselio u Lokve.

Osim tih koji su već došli sa svojim obiteljima, ostali su došli iz obiteljskih razloga, vjerojatno zbog osnivanja obitelji. 
Kada se promatra vremenski aspekt, najmanje se ljudi doselilo nakon Drugoga svjetskog rata, tri osobe. Između dva svjetska rata doselilo se devetnaest osoba, a prije 1918. četrnaest. Za tri osobe vrijeme dolaska nije bilo moguće odrediti.

Kada se analizira prostorni raspored doseljenih u naselja delničke župe, najviše ih je upravo u Delnicama, njih 24. Postoji mogućnost da ih je bilo više, ali to nije moguće tvrditi jer je druga knjiga Stanje duša oštećena i nedostaje nekoliko stranica. Osim u Delnice doseljavalo se i u Zalesinu, Trune i Dedin.

Zabilježene su dvije osobe koje su se odselile u Sloveniju: žena koja se udala u mjesto Vas pri Kostelu i muškarac koji se priženio u mjesto Fara pri Kostelu.

Očekivali smo da će se najviše ljudi doseliti upravo u Delnice, koje su najveće naselje Gorskoga kotara, i da će razlog dolaska biti posao, ali zabilješke u knjigama Stanje duša nisu potvrdile očekivanja. Ljudi su se doseljavali najčešće iz privatnih razloga: zasnivanja obitelji. Je li u tim razlozima prevladala ekonomska računica (je li bilo bolje udati se u Delnice nego u neko drugo mjesto), iz takvih vrsta podataka nije moguće utvrditi. Za mali broj ljudi koji su došli u Delnice može se tvrditi da su razlozi dolaska bili bolji životni uvjeti od onih u naseljima iz kojih su došli.

Očekivali smo i da će se iz slovenskih mjesta doseliti više obrtnika, ali zbog životnih uvjeta sličnih onima u susjednim slovenskim mjestima Delnice nisu bile grad kamo bi se stanovnici slovenskih krajeva željeli odseliti. Više su ih privlačili veći industrijski centri poput Zagreba i Rijeke (KržišnikBukić, 2006: 423).

Neke podatke o doseljavanju, kao i dodatne osobne informacije, možemo dobiti iz školskih imenika, iako ti podaci nisu reprezentativni. ${ }^{14}$

Neke obitelji s djecom školske dobi nisu zapisane u knjige Stanje duša delničke župe. Postoji više mogućih razloga za to. Prvo, te su obitelji zapi-

14 U Osnovnoj školi »Ivan Goran Kovačić« u Delnicama pregledane su: Matična knjiga br. 1. (1858./1859.-1874./1875.), Matična knjiga (1895./1896.-1899./1900.), Matična knjiga br. 4. (1901./1902.-1094./1095.), Matična knjiga br. 5. (1905./1906.-1909./1910.), Matične knjige br. 6. (1910./1911.-1914./1915.), Matična knjiga br. 7. (1915./1916.-1919./1920.), Matična knjiga br. 8. (1920./1921.-1924./1925.), Matična knjiga br. 10. (1935./1936.-1937./1938.), Matična knjiga 11. (1938./1939.-1940./1941.), Državna narodna škola Delnice, Glavni imenik, 1939. - 1959. (knjiga 14.), Glavni imenik osnovne osmogodišnje škole Crni lug (1943./1944.-1950./1951), Osnovna škola Tihovo, Glavni imenik. Razdoblje 1944./1945 -1958./1959., Glavni imenik osnovne osmogodišnje škole Crni Lug, 1954./1955.-1957./1958. i do 1959./1960., Narodna osnovna škola Razloge. Glavni imenik, 1947./1948. - 1966./1967., Osnovna škola Delnice. Glavni imenik 5. - 8. razreda. 1958./1959., Glavni imenik privatnih učenika za niže razrede osnovne škole. 1958.-1962. Osnovna škola Delnice i Osnovna škola Delnice. Matična knjiga 1., 1960.-1961. Od 1. do 506. Sve se matice učenika čuvaju u prostorima osnovne škole u Delnicama. 
sane na stranicama u knjizi delničke župe koje nedostaju. Drugo, obitelji su živjele izvan prostora delničke župe, a djeca su išla u školu u Delnice. Treće, moguće je da je obitelj na prostoru delničke župe živjela samo nekoliko godina te ih stoga župnik nije stigao zabilježiti ili obitelj nije odlazila u crkvu, pa župnik možda nije imao potpuni uvid u situaciju u svojoj župi. Dakako, postoji mogućnost da je više od ovdje navedenih razloga utjecalo na to da se svi podaci iz imenika i učeničkih matica ne podudaraju s podacima iz knjiga Stanje duša.

Iz imenikâ i matica učenika vidi se da su neka djeca polazila školu samo godinu dana i da su se nakon nekog vremena odselila s roditeljima. Neke obitelji i učenici pronađeni su u zabilješkama drugih goranskih župa i škola.

Matice učenika otkrivaju nam da je nakon Drugoga svjetskog rata osim triju obitelji koje su zabilježene u knjigama Stanje duša došlo još barem deset obitelji (Osnovna šola Tihovo, 1944./1945.-1958./1959.; Nacionalna osnovna škola Delnice, 1954./1955.-1959./1960.; Osnovna šola Delnice, 1960.-1961.). Doseljeni su bili iz različitih krajeva Slovenije i različitih zanimanja. Tako je zabilježeno da je jedan otac bio postolar, jedan krojač, jedan mehaničar i jedan šumski radnik. Tri osobe bile su djelatnici Jugoslavenske narodne armije (JNA).

Broj ljudi iz slovenskih krajeva koji su se doselili u Delnice ili u ostala mjesta delničke župe nije bio velik. Iako su Delnice glavno mjesto Gorskoga kotara, nije bilo moguće prepoznati veće migracijske valove doseljavanja. Ako tematiku pogledamo šire, možemo zaključiti da je to bilo očekivano. Delnice nikada nisu bile jako razvijeno industrijsko središte i nisu se mogle mjeriti s Rijekom. S druge strane, mjesto se ne nalazi tik uz granicu poput Čabra ili Prezida, što je dodatno utjecalo na načine doseljavanja iz obližnjih slovenskih krajeva. Zbog te udaljenosti nisu se razvile posebne povezanosti sa slovenskim krajevima kao u nekim drugim područjima poput Čabarskoga kraja (Riman, 2013: 63-84).

Ljudi koji su se doselili došli su uglavnom zbog vjenčanja i osnivanja obitelji. Nekoliko ih je došlo zbog posla. I u tom doseljavanju bitno je razlikovati one koji su došli sami od onih koji su doveli obitelj. Dolasci obitelji bili su brojniji nakon Drugoga svjetskog rata. Koliko se moglo pratiti kretanje tih obitelji, čini se da su u Delnicama ostali samo nekoliko godina, da bi ih se potom ponovno srelo u nekom drugom goranskome mjestu u neko drugo vrijeme. Osim toga nakon Drugoga svjetskog rata vidljiv je i određeni broj ljudi koji su radili u Jugoslavenskoj narodnoj armiji te su u Delnice došli dekretom. 


\section{ŽUPA SV.IZIDORA RATARA U DIVJAKAMA-SKRADU}

Župa Divjake-Skrad ima drugačiju povijest od ostalih župa u Gorskom kotaru. U početku se Skrad razvijao sporo, a brži je razvoj počeo kada je bila dovršena cesta Lujzijana, što je ujedno bio i skoro najvažniji događaj za to naselje. Prema nekim izvorima, smatra se da je dnevno kroz Skrad prolazilo i do tisuću prijevoznika. Tada se u Skradu, kao i u ostalim goranskim mjestima, počinju otvarati prenoćišta, a dodatnu važnost za Skrad imala je željeznica. Sredinom 19. stoljeća središte župe premješteno je iz Divjaka u Skrad.

Župa Divjake-Skrad nastala je 1807. Naselja koja obuhvaća do tada su pripadala župama Brod Moravice i Brod na Kupi (Šisler, 2008: 722).

Iz Knjige stališa duše župe Divjake (DAR, DVD 7, ZM-34-J 226) ${ }^{15}$ vidljivo je da su se osobe na prostor župe doseljavale uglavnom iz okolnih goranskih mjesta. Zabilježeno je petnaest osoba (dvanaest žena i tri muškarca) koje su se doselile iz slovenskih krajeva (tablica 2), od toga osam iz pograničnih slovenskih naselja, šest iz naselja udaljenijih od granice te jedna osoba iz Slovenije. Ni za jednu osobu nije zabilježen podatak o zanimanju. Prema zapisima iz knjige može se zaključiti da su se svi doselili zbog osnivanja obitelji. Za pet osoba ne može se utvrditi vrijeme dolaska, za tri se može tvrditi da su došle do 1918., pet ih je došlo između dva svjetska rata, a dvije nakon Drugoga svjetskog rata.

Iako je broj ljudi koji su se doselili iz slovenskih krajeva relativno malen, iz zabilješki u knjizi Stanje duša može se vidjeti da su se ljudi doseljavali u Skrad tijekom cijelog 20. stoljeća, što je vjerojatno povezano s položajem župe na glavnoj prometnici Rijeka - Zagreb.

15 Knjiga stališa duše župe Divjake (DAR, DVD 7, ZM-34-J 226) u lošem je stanju. Pisana je na latinskom jeziku, stranice knjiga izmiješane su, iako su na nekima listovima brojčane oznake. Knjiga je nestručno restaurirana, ali obiluje podacima. 
Tablica 2. Doseljenici na prostor župe Sv. Izidora ratara u DivjakamaSkradu od sredine 19. do sredine 20. stoljeća prema mjestu odakle su doselili

Table 2. Immigrants in the area of St. Isidore the Labourer Parish in Divjake-Skrad in the period from the mid- $19^{\text {th }}$ to mid- $20^{\text {th }}$ century, by place of emigration

\begin{tabular}{lc|lc}
\hline Slovenska naselja & $\begin{array}{c}\text { Broj } \\
\text { doseljenika }\end{array}$ & Slovenska naselja & $\begin{array}{c}\text { Broj } \\
\text { doseljenika }\end{array}$ \\
\hline Bizeljsko & 1 & Makole & 1 \\
\hline Breznica & 1 & Metlika & 1 \\
\hline Fara & 2 & Podgrad & 1 \\
\hline Harije & 1 & Potoče & 1 \\
\hline Kranj & 1 & Slovenija & 1 \\
\hline Kuželj (slovenski) & 1 & Trbovlje & 1 \\
\hline Loški Potok & 1 & Žalna & 1 \\
\hline \multirow{2}{*}{} & & Ukupno & $\mathbf{1 5}$ \\
\cline { 3 - 4 } & & &
\end{tabular}

\section{ŽUPA SV.IVANA PADOVANSKOG U FUŽINAMA}

Fužine su nastale u 17. stoljeću kada su grofovi Zrinski počeli s iskopavanjem željezne rudače te se prvi put spominju 1649. (Šisler, 2008: 668). Mjesto se razvilo tik uz Karolinšku cestu i gospodarstvo se razvijalo na temelju prometa jer su Fužine bile jedna od važnijih postaja na putu prema bakarskoj i riječkoj luci (Jakovljević, 2000: 13). Poslije je mjesto dobilo željezničku prugu. Poput brojnih drugih mjesta doseljavanje je bilo uvjetovano upravo razvojem cestovnog i željezničkog prometa. U Fužinama je bila važna drvna industrija, koja postaje izrazito važna između dva svjetska rata, kada se moderniziraju stare i grade nove pilane, što dovodi novo stanovništvo $\mathrm{u}$ grad (Jakovljević, 2000: 19).

Župa Fužine osnovana je 1725. Knjige Stališ duša Fužine (DAR, DVD 05, ZM-34-J-218) i Stališ duša župe Fužina (DAR, DVD 05, ZM-34-J-218) redovito su ispunjavane na hrvatskom jeziku, ali nije zabilježeno puno podataka. Vidi se da su se stanovnici odseljavali u okolna mjesta Lokve i Mrkopalj, kao i u veća hrvatska središta, što je zapravo i glavna karakteristika Gorskoga kotara. Zabilježeni su i brojni odlasci na druge kontinente.

U knjigama je zabilježeno pet osoba (tri muškarca i dvije žene) koje su na prostor fužinske župe došle iz slovenskih mjesta, od toga dvoje iz Kostela 
te po jedna osoba iz Ljutomera, Čadrama i Šmarja. Obje žene došle su iz Kostela, mjesta na samoj slovensko-hrvatskoj granici. Kako nije bilo drugih podataka o zaposlenju ili razlozima dolaska, zaključujemo da je svih pet osoba došlo upravo zbog osnivanja obitelji.

Doseljavanje stanovništva u Fužine možemo ilustrirati i podacima dobivenima iz matica učenika osnovne škole u Fužinama. ${ }^{16}$ Već je spomenuto da to nisu reprezentativni podaci, ali svejedno je moguće slijediti doseljavanje čak i cijelih obitelji, što se pri pregledu knjiga Stanje duša nije moglo.

Najviše je učenika rođenih na prostoru Slovenije i slovenske nacionalnosti bilo u mjestu Vrata. Zabilježeno je jedanaest učenika koji su kratko pohađali školu (dvije-tri godine) i oni su zabilježeni do 1918. Dva učenika pohađala su školu školske godine 1925./1926., a očevi te djece radili su u tvornici, ${ }_{17}^{17}$ pa se može zaključiti da su se u Fužine doselili zbog posla. Nakon Drugoga svjetskog rata zabilježeno je doseljavanje dviju obitelji, iz kojih je jedan otac bio zaposlen kao oficir Jugoslavenske narodne armije te je dolazak te obitelji bio najvjerojatnije uvjetovan dekretom.

Zbog udaljenosti Fužina od granice doseljavanje je bilo manje nego što je zabilježeno u goranskim župama u neposrednome pograničnom prostoru. Ni postojeći industrijski pogoni nisu bili dovoljno veliki da privuku ljude iz širega goranskog prostora. Već od 1900. broj ljudi u Fužinama polako se smanjuje, na što je svakako utjecalo i slabo doseljavanje.

\section{ŽUPA SV.KATARINE DJEVICE I MUČENICE U LOKVAMA}

Smatra se da su Lokve jedno od najstarijih naselja u Gorskom kotaru. Župa je osnovana 1806., a crkva sagrađena 1820. (Kovač, 1993: 169). Škola je osnovana 1857. na inicijativu prvog učitelja Jakova Majnarića (Magdić Komadina i Pleše, 1999: 7).

Pregledana je knjiga Status animarum XIX-XX. st. (DAR, 05, ZM-34-J-213, ZM-34-J-214), koja je numerirana. U knjizi nema mnogo zabilješki. Obuhvaća razdoblje od sredine 19. do sredine 20. stoljeća, a zabilježen je dolazak

16 U Osnovnoj školi »Ivanka Troha« u Fužinama bile su pregledane knjige: Obča pučka škola u Liču, Glavni imenik školskih sposobnjaka 1875/1876-1947/1948; Niža pučka škola u Vratima, Državna mješovita pučka škola u Liču, Glavni imenik I. do IV. razreda 1945/1946; O. š. Fužine, Glavni imenik I. do IV. razreda 1946/1947-1948/1949; Osnovna mješovita škola u Liču, Glavni imenik 1948/1949- 1955/1956; Osnovna škola Vrata, Glavni imenik 1950/1951 - 1959/1960; Narodna osnovna osmogodišnja škola Lič, Glavni imenik 1956/1957- 1958/1959; Narodna osnovna osmogodišnja škola Fužine, Glavni imenik 1956/1957-1959/1960; Narodna osnovna osmogodišnja škola Fužine, Glavni imenik 1958/1959-1959/1960.

17 U matičnim knjigama nije zapisano u kojoj su tvornici radili. Možemo samo pretpostaviti da je to tvornica namještaja Mundus, izgrađena i osnovana 1883. (Jakovljević, 2000: 19). 
dviju osoba. Došla je jedna žena iz Velikih Lašč i muškarac iz Šentruperta. Oba su mjesta udaljena od slovensko-hrvatske granice. Muškarac se priženio u Homer između dva svjetska rata, a žena se udala prije Prvoga svjetskog rata.

Više je obitelji zabilježeno u školskim knjigama Osnovne škole »Ivanka Troha « ${ }^{18} \mathrm{U}$ knjigama pohranjenima u prostorima osnovne škole zabilježeno je dvanaest obitelji koje su se od 1862. do 1981. doselile u župu Lokve. Važno je reći da je prema podacima iz imenika vidljivo da su obitelji u župi Lokve boravile kratko. Kod nekih je učenika zabilježeno zanimanje oca. Tako je otac Edmunda Vilfana, Ivan, bio kraljevski poreznik sedamdesetih godina 19. stoljeća (Matica za pučku učionu u Lokvah). Za šest očeva zapisano je da su radili u pilani, a za dvojicu da su bili kovači. Za dva roditelja nije zapisano zanimanje. Majke su uglavnom bile kućanice.

Analizom knjiga Stanje duša i matica učenika moguće je iste obitelji, inače doseljene iz slovenskih krajeva, poslije vidjeti u nekim drugim goranskim mjestima. Tako je zabilježeno da su se dvije obitelji iz Slovenije doselile u Lokve te poslije odselile, i to jedna u Delnice, a druga u Ogulin. Slična situacija bila je s obitelji iz Kočevja koja je neko vrijeme boravila u Delnicama te se potom preselila u Lokve (Glavni imenik o. š. Lokve).

U župi Lokve zabilježen je relativno mali broj doseljenika iz slovenskih krajeva. Zbog udaljenosti mjesta i nerazvijene industrije veći broj doseljenika nije se ni očekivao.

Nejasno je zašto navedene obitelji nisu zabilježene u knjizi Stanje duša. Iako se prema podacima dobivenima iz knjiga učenika čini da je doseljen relativno velik broj učenika, valja naglasiti da je to broj sakupljen u dugom razdoblju (od sredine 19. do sedamdesetih godina 20. stoljeća). Dobiveni podaci pokazuju nam i razloge dolaska cijelih obitelji, a to je najčešće bio posao roditelja u pilani u Lokvama, rjeđe su bili obrtnici, a najmanje je onih koji su došli iz obiteljskih razloga.

18 Pregledane su knjige: Matica za pučku učionu u Lokvah 1858./1859.-1874./1875.; Glavni imenik. Obće pučke škole u Lokvama 1864.-1870.; Glavni imenik, Lokve, 1871. godine; Razrednica III i IV razreda za šk. godinu 1927./1928.; Izpitni izvještaj započet 1. rujna 1936. godine (do 1941; 1944./1945. i 1945./1946.); Matična knjiga od 1. 9. 1967. do 1981. godine; Glavni imenik o. š. Lokve; Ispitno izvješće za godinu 1908./1909.; Osnovna škola Lokve. Matična knjiga, sv. 1. šk. 1960./1961.-1967./1968.; Popis školskih sposobnjaka za šk. g. 1932./1933.; razredni imenici od 1864. do 1981., bez imenika od 1923. do 1930. 


\section{ŽUPA SV.PETRA I PAVLA APOSTOLA U PODSTENAMA}

Sjedište župe Podstene, koja je osnovana u 19. stoljeću, nalazi se u mjestu Kocijani (Kremenić, 2004/2005: 147). Knjigu Stališ duša (DAR, DVD 05, ZM34J-214, MO1806206) sastavio je Antun Mihić, tadašnji upravitelj župe, a podaci u knjizi siromašni su i malo je dodanih zabilješki.

Prema dobivenim podacima vidi se da se na prostor župe doselilo malo ljudi iz današnjih slovenskih krajeva. Iako je mjesto udaljeno od granice samo kilometar, zabilježen je odlazak samo jedne žene u Kočevje zbog udaje (DAR, DVD 05, ZM-34J-214, MO1806206).

Od kraja 19. do sredine 20. stoljeća iz pograničnih slovenskih naselja na prostor župe Sv. Petra i Pavla doselilo se devet osoba: četvero iz Fara te po jedna osoba iz Dola pri Ribnici, Kočevske Reke, Sapnika, Kuželja i Žage. Iz pograničnih je slovenskih mjesta došlo šest osoba, a tri iz udaljenijih mjesta. Svi su se doselili iz osobnih i obiteljskih razloga te su se u hrvatskim mjestima vjenčali. Došlo je pet žena i četiri muškarca.

Iako su mjesta župe Podstene u pograničnom prostoru, pa se s obzirom na smještaj očekivao veći broj doseljenika, razloge za slabo doseljavanje treba tražiti u lošoj prometnoj povezanosti, ali i u činjenici da je cijeli prostor Gorskoga kotara bio zahvaćen jakom depopulacijom, koja je svakako značajna i za slovenski prostor koji graniči s Gorskim kotarom.

\section{ŽUPA SV.TEREZE AKVILSKE U RAVNOJ GORI}

Mjesto Ravna Gora, kao i u nešto manjoj mjeri druga mjesta župe Ravna Gora, među znanstvenicima različitih disciplina pobuđuju velik interes.

Ravna Gora nalazi se približno na pola puta između Rijeke i Karlovca, pa je povoljan geografski položaj pored glavnoga prometnog pravca omogućio naselju brz i dobar razvoj. Godine 1785. naselje je postalo slobodno kraljevsko mjesto, što je uz razvoj prometa pridonijelo brzome razvoju mjesta kao i doseljavanju ljudi iz svih krajeva Austro-Ugarske Monarhije (Šisler, 2008: 719). Važnu ulogu imala je i drvna industrija pa je tako 1808. djelovala pilana u Sušici, 1830. u Ravnoj Gori, a 1860. počela je djelovati parna pilana (Šisler, 2008: 720).

Prostor župe Ravna Gora zapravo je vrlo važan u procesu migracija. Važan je i zbog toga što nam djelomično dočarava što se događa s doseljenim stanovništvom nakon što tri-četiri generacije doseljenih obitelji žive na određenom prostoru. 
Znanstvenici smatraju da se u Ravnu Goru doselilo barem 48 obitelji, što zaključuju prema prezimenima, koja su i danas prisutna u župi Ravna Gora. Tako Pavel Blaznik (1979: 88-89) navodi 48 prezimena, ${ }^{19}$ a potvrdu da su slovenska našao je u škofjološkim urbarima, ali i u drugim dokumentima. Neki hrvatski i slovenski znanstvenici smatraju da je većina doseljenika bila iz Gornje Kranjske (danas Cernice, Idrije, Črnog Vrha i Poljana) (Herljević, 1965: 6). Doseljavanje iz tog prostora usko je povezano s gradnjom ceste krajem 18. stoljeća. Nadalje se navodi da su se doseljenici iz slovenskih krajeva uglavnom doselili u gornji i glavni dio sela (Stari Varoš, Vrh, Sušica) te se i stoga stanovnici tog dijela nazivaju »Kranjcima", a novog dijela »Hrvatima«. Baš je zbog takve podjele postojao antagonizam između staroga (gornjeg) i novoga (donjeg) dijela sela (Podobnik, 2005: 14). ${ }^{20}$

No iako prezimena i stari zapisi otkivaju doseljavanje slovenskog stanovništva, ono iz popisa stanovništva nije vidljivo. Tako se primjerice u popisu iz 1910. samo jedna osoba deklarirala kao Slovenac (Gelo, 1998: 665).

Iako je za prostor župe Ravna Gora pregledan najveći broj knjiga u odnosu na druge župe Gorskoga kotara, u njima nismo našli potvrdu o doseljavanju koju navode spomenuti autori. Knjige obuhvaćaju razdoblje od sredine 19. do sredine 20. stoljeća i nije zabilježen nijedan slučaj doseljavanja stanovništva iz slovenskih mjesta. Ako su spominjane veze i doseljavanja postojali, oni su do sredine 19. stoljeća i prestali. U knjigama je zabilježeno samo masovno iseljavanje, i to u druge dijelove Hrvatske, ali i na druge kontinente. U tome Ravna Gora nije zaostajala za drugim goranskim župama.

Prema nekim izvorima možemo tvrditi da je doseljavanje u daljoj prošlosti postojalo, ali da je ono u tom razdoblju i završilo. Od sredine 19. do sredine 20. stoljeća nije zabilježeno doseljavanje stanovništva slovenskih krajeva. Stanovnici Ravne Gore poznaju svoju povijest. Prema kolektivnoj svijesti stanovništva, njihovi su preci došli iz slovenskih krajeva, ali današnji stanovnici Ravne Gore, četvrta i peta generacija tih doseljenih »Kranjaca«, nemaju više osjećaj slovenske nacionalne pripadnosti. Deklariraju se kao Hrvati i tako se izjašnjavaju pri popisu stanovništva. ${ }^{21}$

19 Prezimena koja se navode kao slovenska jesu: Alič, Bajt, Beuk, Brelih, Božič, Brenc, Brus, Čudeš, Čar(u), Erbič, Erjavec, Grbac, Grebenc (Krebenc), Gregorac, Janež, Jereb, Ješevnik, Kenda, Klobučar, Leban, Liker, Mašon, Mihelič, Miklaič, Novinc, Pintar, Podgornik, Podobnik, Poje, Polak, Poljančič, Použ (Puž), Repic, Rotar, Sedej, Skok, Stucin, Svetličič, Šinkovč, Šmidt, Troha, Vončina, Velikonja, Vic, Vidmar, Vizjak, Zelenak i Žagar (Majnarić, 1938-1939: 146).

20 Majnarić piše da se u povijesti Ravne Gore kroz povijest mogu prepoznati tri razdoblja doseljavanja. Prvim se smatra razdoblje od postanka sela do osmanskih upada, drugo je doseljavanje stanovništva iz Bosne (od 1632. do 1764.), a treće počinje gradnjom Karoline, kada i dolazi stanovništvo iz Slovenije (Majnarić, 1938-1939: 146-149).

21 Iz razgovora sa Z. E., Ravna Gora, srpanj 2013. 


\section{ŽUPA SV.IVANA NEPOMUKA, VRBOVSKO}

Prvi pisani izvori o Vrbovskom (i okolnim naseljima Lukovdolu i Moravicama) spominju se već u 15. stoljeću. Povijest toga kraja povezana je s organizacijom crkvene vlasti i posjedima feudalnih gospodara. Posebnu važnost u promjenama i razvoju Vrbovskog imala je cesta Karolina, što je potaknulo doseljavanje stanovništva iz cijelog prostora Austro-Ugarske Monarhije (Šisler, 2008: 647). Osnovna škola u Vrbovskom otvorena je 1786., potom su otvorene škole i u manjim mjestima na širem prostoru Vrbovskoga. Kulturne institucije nastajale su kada i škola. Bila je osnovana narodna čitaonica, a krajem 19. stoljeća i dobrovoljno vatrogasno društvo (Šisler, 2008: 684).

Iako je crkva izgrađena već 1710., župa Vrbovsko postoji od 1890. (Kovač, 1993: 401). Iz knjige Stališ duša (DAR, DVD 6, ZM34J-226) vidljivo je da su se stanovnici iseljavali u okolna mjesta Gorskoga kotara, ali i u Ogulin i Zagreb te na druge kontinente. Zabilježena je 21 osoba koja se u župu Vrbovsko doselila iz slovenskih mjesta, od toga petnaest žena i šest muškaraca (tablica 3).

Tablica 3. Doseljenici na prostor župe Sv. Ivana Nepomuka u Vrbovskom od 1861. do 1961. prema mjestu odakle su doselili

Table 3. Immigrants in the area of St. John of Nepomuk Parish in Vrbovsko from 1861 to 1961, by place of emigration

\begin{tabular}{ll|ll}
\hline Slovenska naselja & $\begin{array}{l}\text { Broj } \\
\text { doseljenika }\end{array}$ & Slovenska naselja & $\begin{array}{l}\text { Broj } \\
\text { doseljenika }\end{array}$ \\
\hline Bohinjska Bistrica & 1 & Postojna & 1 \\
\hline Cerknica & 1 & Prečna & 1 \\
\hline Fara & 2 & Radoši & 1 \\
\hline Kočevje & 3 & Sežana & 1 \\
\hline Kostel & 1 & Sodražica & 1 \\
\hline Novo Mesto & 1 & Stara Cerkev & 1 \\
\hline Podgraje & 1 & Travnik & 1 \\
\hline Podzemelj & 1 & Vinica & 2 \\
\hline Pohorje & 1 & Ukupno & $\mathbf{2 1}$ \\
\hline
\end{tabular}

U naselja župe Vrbovsko doselilo se devet osoba iz današnjih slovenskih pograničnih mjesta, dok su ostali došli iz mjesta udaljenijih od slovensko- 
hrvatske granice. Za sve je osobe zabilježeno da su se vjenčali. Za četvoricu muškarca zabilježeno je i zanimanje: mlinar, poštar, postolar i krojač.

Najviše ih se doselilo do 1918., njih trinaest, između dva svjetska rata još šest te jedan nakon Drugoga svjetskog rata. Za jednu osobu nije zabilježeno vrijeme dolaska.

Vrbovsko je mjesto koje zbog svojeg položaja nije bilo često pod utjecajem jakih migracija. Razlozi dolazaka privatne su naravi. Broj doseljenih svakako je veći nego u nekim drugim mjestima koja su jednako udaljena od slovensko-hrvatske granice ili čak bliža njoj.

\section{RASPRAVA I ZAKLJUČAK}

Da bi se dobio potpuniji uvid iz kojih se mjesta stanovništvo doseljavalo, potrebno je iznesene podatke usporediti (tablica 4).

Tablica 4. Doseljenici iz slovenskih mjesta u župe Središnjega kraja i Kupske doline

Table 4. Immigrants from Slovenian settlements to the parishes in the Central Region and the Kupa Valley

\begin{tabular}{|c|c|c|c|c|c|c|c|c|c|}
\hline \multirow[b]{2}{*}{ Slovenska naselja } & \multicolumn{8}{|c|}{ Župe Središnjega kraja i Kupske doline } & \multirow[b]{2}{*}{ Ukupno } \\
\hline & 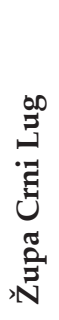 & 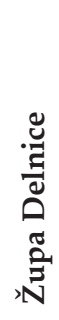 & 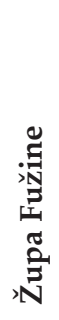 & 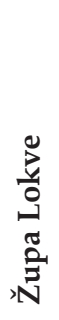 & 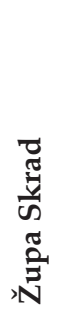 & 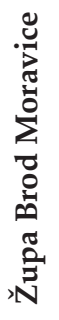 & 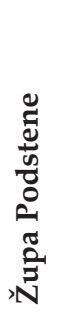 & 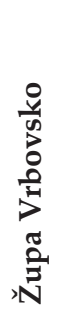 & \\
\hline Banja Loka & & 2 & & & & & & & 2 \\
\hline Bizeljsko & & & & & 1 & & & & 1 \\
\hline Bohinjska Bistrica & & & & & & & & 1 & 1 \\
\hline Borovec & & 1 & & & & & & & 1 \\
\hline Breznica & & & & & 1 & & & & 1 \\
\hline Celje & & 1 & & & & & & & 1 \\
\hline Cerknica & & & & & & & & 1 & 1 \\
\hline Čadram & & & 1 & & & & & & 1 \\
\hline Črneča Vas & & 1 & & & & & & & 1 \\
\hline Dol pri Ribnici & & & & & & & 1 & & 1 \\
\hline
\end{tabular}




\begin{tabular}{|c|c|c|c|c|c|c|c|c|c|}
\hline \multirow[b]{2}{*}{ Slovenska naselja } & \multicolumn{8}{|c|}{ Župe Središnjega kraja i Kupske doline } & \multirow[b]{2}{*}{ Ukupno } \\
\hline & 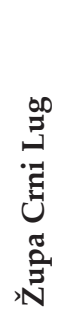 & 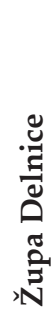 & & 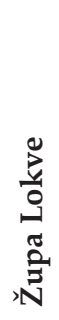 & 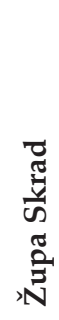 & 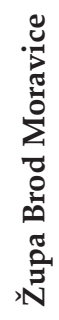 & 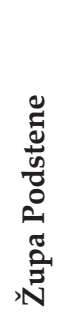 & 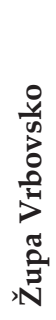 & \\
\hline Dolenja Vas pri Ribnici & 1 & & & & & & & & 1 \\
\hline Fara & 1 & 9 & & & 2 & & 4 & 2 & 18 \\
\hline Grivac & & 1 & & & & & & & 1 \\
\hline Harije & & & & & 1 & & & & 1 \\
\hline Kočevje & 1 & & & & & & & 3 & 4 \\
\hline Kočevska Reka & & & & & & & 1 & & 1 \\
\hline Kostel & & & 2 & & & & & 1 & 3 \\
\hline Kranj & & & & & 1 & & & & 1 \\
\hline Kuželj & & & & & 1 & & 1 & & 2 \\
\hline Ljutomer & & & 1 & & & & & & 1 \\
\hline Lokev & & 1 & & & & & & & 1 \\
\hline Loški Potok & & 1 & & & 1 & & & & 2 \\
\hline Ložec & & 1 & & & & & & & 1 \\
\hline Makole & & & & & 1 & & & & 1 \\
\hline Metlika & & & & & 1 & & & & 1 \\
\hline Nova Sela & & 1 & & & & & & & 1 \\
\hline Novo Mesto & & & & & & & & 1 & 1 \\
\hline Osilnica & & 2 & & & & & & & 2 \\
\hline Pirče & & 2 & & & & & & & 2 \\
\hline Podgorje & & 1 & & & & & & & 1 \\
\hline Podgrad & & & & & 1 & & & & 1 \\
\hline Podgraje & & & & & & & & 1 & 1 \\
\hline Podturn & & 1 & & & & & & & 1 \\
\hline Podzemelj & & & & & & & & 1 & 1 \\
\hline Pohorje & & & & & & & & 1 & 1 \\
\hline Polzela & & 1 & & & & & & & 1 \\
\hline Postojna & & & & & & & & 1 & 1 \\
\hline Potoče & & & & & 1 & & & & 1 \\
\hline Potok & & 1 & & & & & & & 1 \\
\hline Prečna & & & & & & & & 1 & 1 \\
\hline
\end{tabular}




\begin{tabular}{|c|c|c|c|c|c|c|c|c|c|}
\hline \multirow[b]{2}{*}{ Slovenska naselja } & \multicolumn{8}{|c|}{ Župe Središnjega kraja i Kupske doline } & \multirow[b]{2}{*}{ Ukupno } \\
\hline & 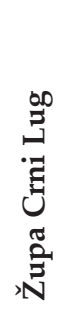 & 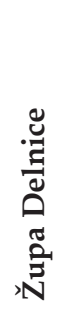 & 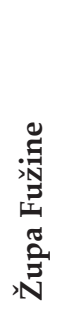 & 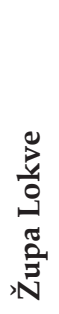 & 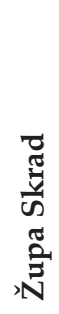 & 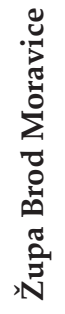 & 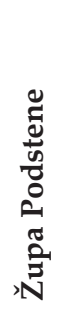 & 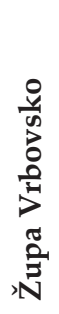 & \\
\hline Preserje & & 1 & & & & & & & 1 \\
\hline Radgona & & 1 & & & & & & & 1 \\
\hline Radoši & & & & & & & & 1 & 1 \\
\hline Rakek & & 1 & & & & & & & 1 \\
\hline Ribnica & & 1 & & & & & & & 1 \\
\hline Sapnik & & & & & & & 1 & & 1 \\
\hline Selo & & 1 & & & & & & & 1 \\
\hline Sežana & & & & & & & & 1 & 1 \\
\hline Slavski Laz & & 1 & & & & & & & 1 \\
\hline Slovenija & & & & & 1 & 3 & & & 4 \\
\hline Slovenska Vas & & 1 & & & & & & & 1 \\
\hline Sodražica & & 1 & & & & & & 1 & 2 \\
\hline Spodnji Log & & & & & & 1 & & & 1 \\
\hline Stara Cerkev & & & & & & & & 1 & 1 \\
\hline Stari Log & & & & & & 1 & & & 1 \\
\hline Stari Trg & & 1 & & & & 1 & & & 2 \\
\hline Šentrupert & & & & 1 & & & & & 1 \\
\hline Šmarje & & & 1 & & & & & & 1 \\
\hline Travnik & & & & & & & & 1 & 1 \\
\hline Trbovlje & & & & & 1 & & & & 1 \\
\hline Trnava & & 1 & & & & & & & 1 \\
\hline Trnovica & & & & & & 1 & & & 1 \\
\hline Vas pri Kostelu & & 2 & & & & & & & 2 \\
\hline Velika Dolina & & & & & & 1 & & & 1 \\
\hline Velika Voda & 1 & & & & & & & & 1 \\
\hline Velike Lašče & & & & 1 & & & & & 1 \\
\hline Vinica & & & & & & 2 & & 2 & 4 \\
\hline Žaga & & & & & & & 1 & & 1 \\
\hline Žalna & & & & & 1 & & & & 1 \\
\hline Ukupno & 4 & 39 & 5 & 2 & 15 & 10 & 9 & 21 & 105 \\
\hline
\end{tabular}


Iz tablice 4 vidljivo je da se u prostor o kojem se ovdje govori od sredine 19. do sredine 20. stoljeća doselilo barem 105 osoba, i to iz različitih slovenskih krajeva. Kad se analizira tablica, vidljivo je da se pojedinci nisu doseljavali iz istih krajeva u ovdje spominjane hrvatske župe. Razlog tome valja tražiti u promatranom prostoru, koji je izdužen, tako da su u pojedina mjesta gravitirali ljudi iz različitih slovenskih pograničnih krajeva. Ističe se naselje Fara, za koje je zabilježen dolazak osoba u pet župa (Crni Lug, Delnice, Skrad, Podstene i Vrbovsko). Zabilježeni su i dolasci osoba iz okolnih mjesta Fare, sa slovenske strane Kupske (Kolpske) doline (Banja Loka, Kostel, Kuželj, Loški Potok, Osilnica itd.). Upravo te veze i doseljavanja upućuju na to da postoji određena povezanost između nekih pograničnih prostora s jedne i druge strane granice. Mjesta razdvojena rijekom povezana su različitim procesima i događajima koji utječu na svakodnevni život, prije svega su to obiteljski razlozi i vjenčanja, iako postoje i drugi. Radi ilustracije, što ujedno upućuje na povezanost točno određenih hrvatskih i slovenskih pograničnih krajeva, ističemo da prilikom analize doseljavanja stanovništva iz slovenskih krajeva u mjesta župa Čabarskoga kraja nije zabilježena nijedna osoba koja se na taj prostor doselila iz ovdje navedenih slovenskih pograničnih mjesta (Fare, Banja Loke itd.) (Riman, 2013: 79-80).

Sakupljeno gradivo moguće je osim prema slovenskim mjestima analizirati ovisno o spolu doseljenika i vremenu njihova dolaska (tablica 5). 
Tablica 5. Doseljenici prema prostoru odlaska, spolu i vremenu dolaska u Središnji kraj i Kupsku dolinu

Table 5. Immigrants in the Central Region and the Kupa Valley, by departure area, gender and time of arrival

\begin{tabular}{|c|c|c|c|c|c|c|c|c|c|}
\hline \multirow[b]{2}{*}{$\begin{array}{l}\text { Župe Središnjega } \\
\text { kraja i Kupske } \\
\text { doline }\end{array}$} & \multicolumn{2}{|c|}{$\begin{array}{l}\text { Prostor } \\
\text { odlaska }\end{array}$} & \multicolumn{2}{|c|}{ Spol } & \multicolumn{4}{|c|}{ Vrijeme dolaska } & \multirow[b]{2}{*}{ Ukupno } \\
\hline & 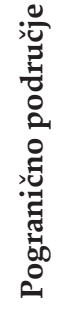 & 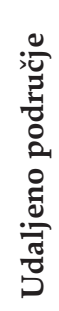 & 氖 & 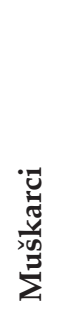 & $\begin{array}{l}\infty \\
\stackrel{\infty}{\sigma} \\
\stackrel{2}{0} \\
\stackrel{0}{0}\end{array}$ & 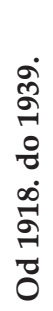 & 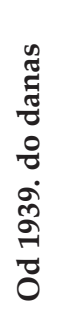 & 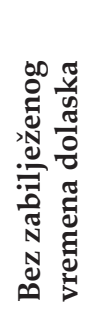 & \\
\hline Župa Brod Moravice & 3 & 7 & 7 & 3 & 3 & 2 & 2 & 3 & 10 \\
\hline Župa Crni Lug & 4 & 0 & 2 & 2 & 0 & 4 & 0 & 0 & 4 \\
\hline Župa Delnice & 27 & 12 & 20 & 19 & 14 & 19 & 3 & 3 & 39 \\
\hline Župa Divjake-Skrad & 8 & 7 & 12 & 3 & 3 & 5 & 2 & 5 & 15 \\
\hline Župa Fužine & 2 & 3 & 2 & 3 & 3 & 2 & 0 & 0 & 5 \\
\hline Župa Podstene & 6 & 3 & 4 & 5 & 3 & 3 & 2 & 1 & 9 \\
\hline Župa Lokve & 0 & 2 & 1 & 1 & 1 & 1 & 0 & 0 & 2 \\
\hline Župa Vrbovsko & 9 & 12 & 15 & 6 & 13 & 6 & 1 & 1 & 21 \\
\hline Ukupno & 59 & 46 & 62 & 41 & 39 & 41 & 10 & 13 & 105 \\
\hline
\end{tabular}

Iz tablice 5 vidljivo je da se u Središnji kraj i Kupsku dolinu doselilo, prema očekivanjima, više ljudi iz pograničnog prostora. Od toga je bilo više žena. Najviše je zabilježenih doseljavanja između dva svjetska rata, dok ih je manje bilo prije 1918. Najmanje doseljenih pojedinaca zabilježeno je nakon Drugoga svjetskog rata.

Može se zaključiti da je u vremenu kada je u Gorskom kotaru zabilježena jaka depopulacija stanovništva ipak zabilježeno i doseljavanje.

Dobiveni podaci govore nam da se stanovništvo uglavnom doseljava iz pograničnih mjesta, i to iz slovenskog dijela Kupske doline. Veći je broj doseljenih žena nego muškaraca te ih je najviše došlo između dva svjetska rata.

Potvrđena su očekivanja iznesena na početku ovoga rada. U mjestima župa bliže slovensko-hrvatskoj granici zabilježen je veći broj dolazaka zbog vjenčanja i osnivanja obitelji, i to uglavnom iz mjesta koja su danas na dru- 
goj strani granice. Tako se može tvrditi da su u naselja u župi Crni Lug ili Skrad pojedinci dolazili isključivo zbog ženidbe ili udaje.

U nekim je mjestima broj doseljenika zbog osnivanja obitelji i traženja zaposlenja bio podjednak (Delnice, Vrbovsko), dok su u nekima prevladavali pojedinci (i obitelji) koji su došli isključivo zbog lakšeg zaposlenja, odnosno boljeg života. Dolazak zbog posla uočen je prije svega u župama udaljenijima od granice. Svakako valja spomenuti župu Lokve, gdje je zabilježen dolazak kraljevskog poreznika, šest radnika u pilani te dva kovača. Osim njih zabilježeni su dolasci ljudi s obrtničkim zanimanjima: postolar, mehaničar, krojač i kovači. No čini se da su ti ljudi u tim mjestima ostajali relativno kratko, te se neki od njih susreću u različitim mjestima Gorskoga kotara.

S druge strane, zabilježen je i određeni broj pojedinaca i njihovih obitelji koji su se u Gorski kotar doselili zbog premještaja. To su pseudodobrovoljne migracije, većinom oficirâ i drugog vojnog osoblja nekadašnje Jugoslavenske narodne armije. Ti pojedinci (državni službenici) koji su se doselili s obiteljima najčešće su zabilježeni nakon Drugoga svjetskog rata.

Za neka se pogranična mjesta očekivao veći broj doseljenika od zabilježenih u knjigama Stanje duša, primjerice u onima u župi Brod Moravice. Upravo je u tim slučajevima vidljivo koliko su bitni vanjski čimbenici migracija. Može se zaključiti da je u nekim mjestima broj doseljenika bio manji i zato što su mjesta bila (i danas su) loše prometno povezana sa slovenskim i hrvatskim krajevima.

Posebni pogled na prekogranične migracije daju podaci dobiveni iz matice učenika, gdje se vidi jaka povezanost pograničnih mjesta s određenim školama Središnjega kraja i Kupske doline. Zabilježeni su svakodnevni dolasci na nastavu u obližnje pogranične škole (Plemenitaš, Severin na Kupi, Lukovdol, Veliki Jadruć, Brod na Kupi i sl.). Podaci u tim školskim imenicima i maticama učenika nisu bitni za doseljavanje stanovništva u pogranični prostor, nego zato što upućuju na pogranično povezivanje stanovništva i svakodnevne migracijske tokove koji dosad još nisu istraženi. Čini se da je slična situacija i sa školom u Čabru (i drugim školama Čabarskoga kraja). Ti su podaci svakako važni i za povijest školstva. Dosad još nisu analizirani uvjeti školovanja djece u prošlosti u ruralnim prostorima.

Slična bi istraživanja u prostoru koji graniči s Republikom Slovenijom svakako potvrdila ovdje iznesene zaključke, te možemo tvrditi da bi ovdje prikazani i opisani procesi bili slični duž cijele današnje slovensko-hrvatske granice. 
Podacima iz knjiga Stanje duša moguće je dakle individualizirati migracije i detaljnije odrediti razloge (prirodu) doseljavanja. U radu je zahvaćeno relativno veliko geografsko područje i dugo razdoblje. Kada bi se ovom metodom i na temelju ovdje predstavljenih izvora podataka pristupilo parcijalnom istraživanju i interpretaciji sakupljenih podataka, vjerojatno bi prikaz ženidbeno-udajnih i obiteljskih veza (prije svega za mjesta bliža granici) bio detaljniji i raznovrsniji. U tom bi slučaju bilo potrebno analizirati ostale crkvene knjige (knjige rođenih, umrlih i prije svega knjige vjenčanih) slovenskih, ali i hrvatskih župa.

Istraživanje je upozorilo na važnost razlikovanja organiziranih i spontanih migracija te na razloge zbog kojih su pojedinci promijenili životnu okolinu. Može se zaključiti da su se pojedinci iz slovenskih mjesta u promatrani prostor doseljavali prije svega iz osobnih razloga i da taj proces kontinuirano traje od sredine 19. do kraja 20. stoljeća.

Analizom podataka dobivenih iz knjiga Stanje duša i njihovim smještanjem u kontekst vremena, od sredine 19. do sredine 20. stoljeća, vide se određene zakonitosti i procesi, prema kojima se, kada se usporede s procesima doseljavanja u mjesta župa Čabarskoga kraja, može zaključiti da su ovdje evidentirati procesi karakteristični za pogranična područja i da ih je moguće pronaći (izmijenjene ili ne) u cijelom prostoru slovensko-hrvatske granice.

\section{IZVORI}

DAR (Državni arhiv u Rijeci), Knjiga stališa duše župe Divjake, DVD 7, ZM-34-J 226

DAR (Državni arhiv u Rijeci), Stališ duša Delnice, Status animarum XIX-XX. st., DVD 4, ZM-34J-210/ZM-34J-211

DAR (Državni arhiv u Rijeci), Stališ duša Fužine, DVD 05, ZM-34-J-218

DAR (Državni arhiv u Rijeci), Stališ duša Ravna Gora, DVD 6, ZM34J-223

DAR (Državni arhiv u Rijeci), Stališ duša Ravnogorci, DVD 6, ZM34J-223

DAR (Državni arhiv u Rijeci), Stališ duša župe Brod-Moravice, DVD 4, ZM-34J-206

DAR (Državni arhiv u Rijeci), Stališ duša župe Crni Lug, DVD 04, ZM-34J-207

DAR (Državni arhiv u Rijeci), Stališ duša župe Fužina DVD 05, ZM-34-J-218

DAR (Državni arhiv u Rijeci), Stališ duša župe Kocijani, DVD 05, ZM-34J-214

DAR (Državni arhiv u Rijeci), Stališ duša, DVD 6, ZM34J-226

DAR (Državni arhiv u Rijeci), Status animarum 1906-1950, DVD 6, ZM34J-223

DAR (Državni arhiv u Rijeci), Status animarum 1906-1950, DVD 6, ZM34J-224

DAR (Državni arhiv u Rijeci), Status animarum XIX-XX. st. DVD 05, ZM -34-213 (LOKVE)

DAR (Državni arhiv u Rijeci), Svezak II, Status animarum XIX-XX. st., DVD 4, ZM-34J-210/ ZM-34J-211 
Državna mješovita pučka škola u Liču, Osnovna škola »Ivanka Trohar«, Fužine

Državna narodna škola Delnice. Glavni imenik, 1939.-1959. (knjiga 14.), Osnovna škola »Ivan Goran Kovačić«, Delnice

Glavni imenik 1956/1957-1958/1959, Osnovna škola »Ivanka Trohar«, Fužine

Glavni imenik 1956/1957-1959/1960, Osnovna škola »Ivanka Trohar«, Fužine

Glavni imenik 1958/1959-1959/1960, Osnovna škola»Ivanka Trohar«, Fužine

Glavni imenik I. do IV. razreda 1945/1946, Osnovna škola »Ivanka Trohar«, Fužine

Glavni imenik o. š. Lokve, Osnovna škola »Rudolfa Strohala«, Lokve

Glavni imenik osnovne osmogodišnje škole Crni Lug, 1954./1955.-1957./1958. i do 1959./1960., Osnovna škola »Ivan Goran Kovačić«, Delnice

Glavni imenik osnovne osmogodišnje škole Crni lug. (1943./1944.-1950./1951), Osnovna škola »Ivan Goran Kovačić«, Delnice

Glavni imenik privatnih učenika za niže razrede osnovne škole. 1958.-1962., Osnovna škola »Ivan Goran Kovačić«, Delnice

Glavni imenik školskih sposobnjaka 1875/1876-1947/1948, Osnovna škola »Ivanka Trohar«, Fužine

Glavni imenik, Lokve, 1871. godine, Osnovna škola »Rudolfa Strohala«, Lokve

Glavni imenik. Obće pučke škole u Lokvama 1864.-1870., Osnovna škola »Rudolfa Strohala«, Lokve

Ispitno izvješće za godinu 1908./1909., Osnovna škola »Rudolfa Strohala«, Lokve

Izpitni izvještaj započet 1. rujna 1936. godine (do 1941; 1944./1945. i 1945./1946.), Osnovna škola »Rudolfa Strohala«, Lokve

Matica za pučku učionu u Lokvah 1858./1859.-1874./1875., Osnovna škola »Rudolfa Strohala«, Lokve

Matična knjiga (1895./1896.-1899./1900.), Osnovna škola »Ivan Goran Kovačić«, Delnice

Matična knjiga 1. 1960.- 1961. Od 1. do 506. , Osnovna škola »Ivan Goran Kovačić«, Delnice

Matična knjiga br. 1. (1858./1859.-1874./1875.), Osnovna škola »Ivan Goran Kovačić«, Delnice

Matična knjiga br. 11. (1938./1939.-1940./1941.), Osnovna škola »Ivan Goran Kovačić«, Delnice

Matična knjiga br. 4. (1901./1902.-1904./1905.), Osnovna škola »Ivan Goran Kovačić«, Delnice

Matična knjiga br. 5. (1905./1906.-1909./1910.), Osnovna škola »Ivan Goran Kovačić«, Delnice

Matična knjiga br. 7. (1915./1916.-1919./1920.), Osnovna škola »Ivan Goran Kovačić«, Delnice

Matična knjiga br. 8. (1920./1921.-1924./1925.), Osnovna škola »Ivan Goran Kovačić«, Delnice

Matična knjiga br.10. (1935./1936.-1937./1938.), Osnovna škola »Ivan Goran Kovačić«, Delnice

Matična knjiga od 1. 9. 1967. do 1981. godine, Osnovna škola »Rudolfa Strohala«, Lokve

Matične knjige br. 6. (1910./1911.-1914./1915.), Osnovna škola »Ivan Goran Kovačić«, Delnice 
Narodna osnovna osmogodišnja škola Fužine, Osnovna škola »Ivanka Trohar«, Fužine

Narodna osnovna osmogodišnja škola Lič, Osnovna škola »Ivanka Trohar«, Fužine

Narodna osnovna škola Razloge. Glavni imenik, 1947./1948.-1966./1967, Osnovna škola »Ivan Goran Kovačić«, Delnice.

Niža pučka škola u Vratima, Osnovna škola »Ivanka Trohar « Fužine

O. š. Fužine, Glavni imenik I. do IV. razreda 1946/1947-1948/1949, Osnovna škola »Ivanka Trohar«, Fužine

Obča pučka škola u Liču, Osnovna škola »Ivanka Trohar«, Fužine

Osnovna mješovita škola u Liču, Glavni imenik 1948/1949-1955/1956, Osnovna škola »Ivanka Trohar«, Fužine

Osnovna škola Lokve, Matična knjiga, sv. 1. šk. 1960./1961.-1967./1968., Osnovna škola »Rudolfa Strohala«, Lokve

Osnovna škola Delnice, Glavni imenik 5.-8. razreda. 1958./1959., Osnovna škola »Ivan Goran Kovačić«, Delnice

Osnovna škola Tihovo, Glavni imenik. Razdoblje 1944./1945.-1958./1959., Osnovna škola »Ivan Goran Kovačić«, Delnice

Osnovna škola Vrata, Glavni imenik 1950/1951-1959/1960, Osnovna škola »Ivanka Trohar«, Fužine

Popis školskih sposobnjaka za šk. g. 1932./1933., Osnovna škola »Rudolfa Strohala«, Lokve Razrednica III i IV razreda za šk. godinu 1927./1928., Osnovna škola »Rudolfa Strohala«, Lokve

\section{LITERATURA}

Bertoša, S. (2000). Puljske matične knjige kao izvor za povijest migracija: doseljenici iz središnje Hrvatske, Ugarske i slovenskih zemalja pod austrijskom vlašću (16131817), Povijesni prilozi, 19 (19): 181-198.

Bertoša, S. (2001). Doseljenici iz Kopra i njegove okolice u puljskim matičnim knjigama od 1613. do 1817., Acta Histriae, 9 (2): 389-414.

Blaznik, P. (1979). O preselitvi loških podložnikov, Loški razgledi, 26 (26): 77-89.

Bognar, A., Pavić, R., Riđanović, J., Rogić, V. i Šegota, T. (1975). Geografija SR Hrvatske, sv. 4. Zagreb: Školska knjiga.

Bognar, I. H. i Bognar, A. (2010). Povijesni razvoj i političko-geografska obilježja granice i pograničja Republike Hrvatske s Republikom Slovenijom na Žumberku i u Kupskočabranskoj dolini, Geoadria, 15 (1): 187-224.

Borovac, I. (2002). Veliki atlas Hrvatske. Zagreb: Mozaik knjiga.

Burić, A. (1983). Povijesna antroponimija Gorskog kotara u Hrvatskoj 1438-1975: goranska prezimena kroz povijest. Rijeka: Društvo za zaštitu prirodne kulturne i povijesne baštine Gorskog kotara.

Drnovšek, M. (1995). Slovenski izseljenci na Hrvaškem do 1914, u: V. Kržišnik-Bukić (ur.). Slovenci v Hrvaški. Ljubljana: Inštitut za narodnostna vprašanja, 107-114.

Drnovšek, M. (2012). Slovenski izseljenci in Zahodna Evropa v obdobju prve Jugoslavije. Ljubljana: Založba ZRC, ZRC SAZU. 
Gelo, J. (1998). Narodnosni i vjerski sastav stanovništva Hrvatske:1880.-1991. po naseljima, sv. 4. Zagreb: Državni zavod za statistiku.

Herljević, A. (1965). Ravna Gora, Vjesnik Historijskih arhiva u Rijeci i Pazinu 10: 5-60.

Horvat, J. (1980). Kultura Hrvata kroz 1000 godina. Zagreb: Globus.

Jakovljević, M. (ur.) (2000). S glazbom u novi milenij: uz 150 godina fužinarske glazbe. Fužine: Kulturno-umjetničko društvo »Vrelo« - Limena glazba Fužine.

Josipovič, D. (2006). Učinki priseljevanja v Slovenijo po drugi svetovni vojni. Ljubljana: Založba ZRC, ZRC SAZU.

Jurković, V. (1969). Brod-Moravice: 150-godišnjica Osnovne škole, 1818-1968: 100-godišnjica školske zgrade, 1869-1969. Brod-Moravice: Osnovna škola Brod-Moravice.

Knežević-Hočevar, D. (1999). Družbena razmejevanja v dolini zgornje Kolpe. Ljubljana: Založba ZRC, ZRC SAZU.

Kovač, M. D. (1993). Stare slave domovina. Hanau: Hrvatska katolička misija.

Kremenić, D. (2004/2005). Kapelice i križevi Brodkupske doline, Etnološka tribina, 34/35 (27-28): 173-183.

Kržišnik-Bukić, V. (1994/1995). Okvirni pregled poteka, vzrokov in pomena izseljevanja Slovencev na Hrvaško, Razprave in gradivo, 5 (29-30): 85-93.

Kržišnik-Bukić, V. (2006). Znameniti Slovenci na Hrvaškem skozi zgodovino, Migracijske i etničke teme, 22 (4): 421-445.

Kuzmič, M. (1995). Izseljevanje iz Prekmurja med prvo in drugo svetovno vojno v luči sodelavcev »Mladega Prekmurca«, Zbornik soboškega muzeja, 4 (4): 103-110.

Lajić, I. i Klempić Bogadi, S. (2010). Demografska budućnost Gorskog kotara, Migracijske i etničke teme, 26 (2): 191-212.

Magdić Komadina, Z. i Pleše, M. (1999). 140 godina osnovnog školstva u Lokvama. Lokve: Osnovna škola Lokve.

Majnarić, N. (1938-1939). Jedno rovtarsko narječje u Gorskom Kotaru. Beograd.

Malnar, S. (2007). Povijest čabarskog kraja. Čabar: Ogranak Matice hrvatske, Grad Čabar.

Mateljan Radovanović, S. (1981). Delnice: 1481-1981. Delnice - Rijeka: Mjesna zajednica - Centar za historiju radničkog pokreta i NOR Istre, Hrvatskog primorja i Gorskog kotara.

Melik, A. (1959). Posavska Slovenija. Ljubljana: Slovenska matica.

Nejašmić, I. (1991). Depopulacija u Hrvatskoj. Zagreb: Globus.

Podobnik, G. (2005). Zavičaju. Ravna Gora: Općina Ravna Gora.

Riman, B. (2013). Doseljavanje stanovništva iz slovenskih krajeva u Čabarski kraj na temelju zabilješki u knjigama Status animarum, Migracijske i etničke teme, 29 (1): 63-88, doi: 10.11567/met.29.1.3.

Senčić, A. (2000). Popis pučanstva župe Mošćenice iz godine 1801: knjiga Stališ duša. Opatija: Katedra Čakavskog sabora.

Stipetić, V. i Vekarić, N. (2004). Povijesna demografija Hrvatske. Zagreb - Dubrovnik: Hrvatska akademija znanosti i umjetnosti, Zavod za povijesne znanosti u Dubrovniku.

Šafar, J. (ur.) (1981). Gorski kotar. Delnice: Fond knjige »Gorski kotar«.

Šisler, S. (ur.) (2008). Gradovi i općine Republike Hrvatske. Zagreb: »Mato Lovrak«. 
Šuštar, B. (2010). Poklicne migracije slovenskega učiteljstva od habsburških do jugoslovanskih časov, u: P. Štih i B. Balkovec (ur.). Migracije in slovenski prostor od antike do danes. Ljubljana: Zveza zgodovinskih društev Slovenije, 209-224.

Žigulić, R. (2008). Stališ duša župe Veprinac: 1875.-1925. Rijeka: Državni arhiv u Rijeci. 


\title{
The Immigration of People from Slovenian Regions to the Parishes in the Central Region and the Kupa Valley Based on the Notes from Ecclesiastical Status Animarum Books from the Mid-19th to Mid- $20^{\text {th }}$ Century
}

\section{Barbara Riman}

\begin{abstract}
SUMMARY
Different migration processes caused the present heterogeneous composition of the population of the Gorski kotar region. The Central Region and the Kupa Valley were not an exception, and the immigration of people from various parts of the Habsburg Monarchy have been recorded throughout history. The reasons for immigration and for its intensity can be seen in the notes written down in the church books named Status Animarum (cro. Stanje duša, slo. Družinske knjige) in which the motives for immigration or emigration of individuals as well as of whole families have been noted. On the basis of these data we can draw generalized conclusions for the precise geographical area, and the precise political and historical period. The paper analyzes data on immigration in the Kupa Valley, with a focus on population migration from today's Slovene regions from the mid- $19^{\text {th }}$ to mid- $20^{\text {th }}$ century. The data obtained from the Status Animarum books written in the parishes of the Central Region and the Kupa Valley, show the immigration of people, which proves migration from Slovenian regions to the Croatian ones, but also vice versa. The conclusions of the paper are illustrated and backed with data from the elementary schools registers in the settlements Brod Moravice, Brod na Kupi, Crni Lug, Delnice, Divjake, Fužine, Lokve, Skrad, Razloge and Vrbovsko.
\end{abstract}

KEY WORDS: Status Animarum, Central Region, Kupa Valley, Slovenian population immigration 